Int. J. Dev. Biol. 51: 397-407 (2007)

doi: $10.1387 / \mathrm{ijdb} .062255 \mathrm{mr}$

Original Article

\title{
Inadvertent presence of pluripotent cells in monolayers derived from differentiated embryoid bodies
}

\author{
MIGUEL A. RAMÍREZ\#, EVA PERICUESTA\#, RAÚL FERNÁNDEZ-GONZÁLEZ, BELÉN PINTADO \\ and ALFONSO GUTIÉRREZ-ADÁN* \\ Department of Animal Reproduction, INIA, Madrid, Spain
}

\begin{abstract}
The therapeutic use of embryonic stem (ES)-derived cells is restricted by a risk of teratoma formation. To test the hypothesis that some cells with pluripotency characteristics remain following the differentiation of embryoid bodies (EB) into monolayer cells, we transformed mouse ES cells using constructs comprised of the mTert promoter coupled to green fluorescent protein. In this manner, EBs could be identified as showing gradually diminishing expression of the fluorescent marker as a consequence of differentiation. After 2 weeks of incubation, however, small groups of fluorescent cells remained in the differentiated monolayer. When these cells were isolated, cultured and expanded under ES cell culture conditions, they recovered their ES cell morphology (herein denoted ES-EB). We found by immunocytochemistry, reverse transcriptionPCR and bisulphite analysis that despite the fact that some of these ES-EB lost their capacity to express some pluripotency markers characteristic of ES cells and undergo the epigenetic modification (hypo-methylation) of some retrotransposons (RT), after several passages in ES media, the cell colonies recovered their capacity for both pluripotency marker expression and RT methylation. Furthermore, when assessed for their ability to form chimeras, most ES-EB lines were unable to do so, although they recovered this potential for chimera production after some passages in ES cell media. Our results highlight the need for specific screening of differentiated cells before their therapeutic use and indicate that under adequate culture conditions, cells that loose their potential for expressing key markers of pluripotency can recover this fundamental embryonic stem cell property.
\end{abstract}

KEY WORDS: mouse, differentiation, pluripotency marker, qRT-PCR marker, ES cell

\section{Introduction}

Embryonic stem (ES) cells can differentiate into most adult cell types and have attracted intense interest because of their potential therapeutic applications (O'Shea, 2004). Thus, if their differentiation could be controlled, cultured ES cells would be an excellent source of cells for transplantation to replace cells lost through disease or injury or cells lacking hormones or genes. Although the therapeutic potential of ES-derived cells is huge, several problems such as teratoma formation have yet to be resolved (Drukker et al., 2002). Each stem-cell transplant may contain cells that had failed to differentiate and which remained undifferentiated. These cells keep dividing and can turn into tumours (Roy et al., 2006). The main pathway through which ESderived cells become differentiated cells involves the formation of embryoid bodies "EB", thus denoted because of their similarity to the early postimplantation embryos. Embryoid bodies form after several days of growth of ES cells in the absence of LIF (leukemia inhibitory factor). These bodies are the final ES cell population that has the potential to give rise to all the cell types of adult tissues and have been described as the developmental equivalent of the egg cylinder-stage mouse embryo, with an outer endodermal layer and a core of differentiating cells, often comprised of epithelial-lined cavities. In this last case, the embryoid bodies are referred to as cystic EBs (O'Shea, 2004). It has been reported that cells derived from all germ layers differentiate into EBs, in some ways recapitulating in vivo gene-expression patterns (Leahy et al., 1999). Because only the outer endoderm of the EB is exposed to added growth factors and cells inside an EB differentiate in response to signals produced by the differentiating endoderm, the

Abbreviations used in this paper: ES, embryonic stem; EB, embryoid body; IAP, intracisternal-A particle; MuERV-L, murine endogenous retrovirus-L; LIF, leukemia inhibitory factor; RT, retrotransposon.

\footnotetext{
*Address correspondence to: Alfonso Gutiérrez-Adán. Departamento de Reproducción Animal INIA, Ctra. de La Coruña Km 5.9, 28040 Madrid, Spain. Tel: +34-91-347-3768. Fax: +34-91-347-4014. e-mail: agutierr@inia.es
}

\# Note: These authors contributed equally to this work 
incomplete differentiation of ES cells is commonly observed in EB and could be related to the fact that differentiated cells, particularly mesoderm cells, produce LIF (O'Shea, 2004). The pluripotency of the EB is lost during the process of differentiation. However, the differentiated EB and the monolayer cells it generates, form a mixture of multiple cell types, with the possibility that some multipotent cells remain. These persisting undifferentiated cells could be the origin of teratoma formation. Also, in monolayer culture derived from teratocaricinoa embryoid bodies it has been reported the presence of four stable cell populations (Hilario et al., 2001). The authors suggest that intrinsic mechanisms of regulation may exist that would strike a balance between differentiation and proliferation.

Telomerase is an enzyme complex that maintains the ends of all eukaryotic linear chromosomes. Murine ES cells have been shown to exhibit high telomerase activity, which is strictly regulated during cell differentiation (Albanell et al., 1996, Armstrong et al., 2000). The murine reverse transcriptase unit (mTert) of telomerase is the catalytic subunit of the telomerase complex and is closely linked to telomerase activity (Armstrong et al., 2000, Pericuesta et al., 2006). In a previous paper, we reported that ES cell telomerase expression levels induced by the mTert promoter diminish as differentiation progresses (Pericuesta et al., 2006). In the present study, we transformed the R1 ES cell line to express green fluorescent protein (GFP) under the control of the mouse telomerase reverse transcriptase promoter (mTert). Our findings indicate that this promoter regulates GFP expression in ES cells during their in vitro loss of pluripotency and therefore enables cells with telomerase activity to be identified and isolated from the monolayer of differentiated cells generated from EBs. We also explored the potential of these ES-like multipotent cells (ES-EB) to recover their ES cell characteristics.

\section{Results}

\section{Recovery of ES-like cells from monolayers of differentiated EBs}

We created six R1-mTert-GFP marked cell lines by stably transfecting with a $4.5 \mathrm{~kb}$ fragment of the mouse telomerase reverse transcriptase promoter (mTert) into murine R1 ES cells (passage 14) (Pericuesta et al., 2006). For the rest of the experiments, we selected a clone (R1-mTert-GFP) that exhibited a good expression of the GFP, a normal karyotype (more that $80 \%$ of normal metaphases, similar to the percentage of the original R1 ES cells) and was capable of chimera transmission $(24 \%$ of chimeras after transfer of 100 embryos, with a 15 to $50 \%$ of coat colour chimerism). This ES cell line has been frozen-thawed and cultured for more than 20 passages without loss of ES morphology or the normal karyotype. All the experiments were performed using ES cells between passages 15 to 20. Moreover, this ES cell
TABLE 1

\section{MRNA EXPRESSION OF PLURIPOTENCY MARKERS}

1 R1-mTert-GFP ES-EB1 ES-EB2 ES-EB3 ES-EB4 ES-EB5 ES-EB6 ES-EB7 ES-EB8 P2 P7 P2 P10 P2 P7 P2 P10

$\begin{array}{cccc}\text { p3 } & \text { p3 } & \text { p3 } & \text { p3 } \\ + & + & + & +\end{array}$

\begin{tabular}{lllllllllllll}
+ & + & + & + & + & + & + & + & + & + & + & + & + \\
+ & - & + & - & + & - & + & - & + & - & - & + & + \\
+ & - & + & - & + & - & + & - & + & - & - & + & + \\
+ & - & + & + & + & + & + & + & + & + & + & + & + \\
+ & - & + & - & + & - & + & + & + & + & + & + & + \\
+ & + & + & + & + & + & + & + & + & + & + & + & + \\
+ & - & + & - & + & + & + & + & + & + & + & + & + \\
+ & - & + & - & + & + & + & - & + & + & + & + & + \\
+ & - & - & - & - & - & - & - & - & - & - & - & + \\
\hline
\end{tabular}

TABLE 2

\section{mRNA EXPRESSION OF MARKERS OF DIFFERENTIATED PHENOTYPES}

$\begin{array}{llllllll}\text { R1-mTert-GFP ES-EB1 } & \text { ES-EB2 } & \text { ES-EB3 } & \text { ES-EB4 } & \text { ES-EB5 } & \text { ES-EB6 } & \text { ES-EB7 } & \text { ES-EB8 }\end{array}$ \begin{tabular}{llllllllllll}
\hline p2 & p7 & p2 & p10 & P2 & p7 & p2 & p10 & p3 & p3 & p3 & p3
\end{tabular} pluripotency present in the R1 ES cell line used for transformation (Table 1). In the presence of LIF, the transgenic ES cell line expressed GFP (Fig 1A); 4 days after removal of LIF and plating the cells into bacterial-grade Petri dishes, the ES cells spontaneously transformed into embryoid bodies (EBs) (Fig 1B). During this process, GFP expression increased. The next step in the EBs differentiation process led to transformation of the EBs into a differentiated monolayer of cells incapable of GFP expression (Fig 1C, D). Nevertheless, groups of GFP expressing cells persisted among the differentiated colonies; even 12 days after LIF had been removed from the EBs differentiating culture (Fig. 1D). After picking GFP-positive groups of cells and culturing in ES cell medium for 2 passages, they recovered their original ES cell morphology. We denoted those cells as ES-EB cells. From the 53 groups of GFP cells that were isolated we produced 23 new green ES-like lines that were maintained in culture and that showed typical ES cell characteristics, including their distinctive large nucleus-to-cytoplasm ratio. These clones were selected because they contained more than $90 \%$ positive cells for the GFP (counted under fluorescent microscopy). Also, to analyze the homogeneity of the population, some of the lines were analyzed by flow cytometry (Fig 2), confirming that the lines contained more that $90 \%$ positive cells for GFP. In contrast, isolated GFP-negative cells were unable to recover the typical ES cell morphology after culture in ES cell media during more than 30 days. These groups 

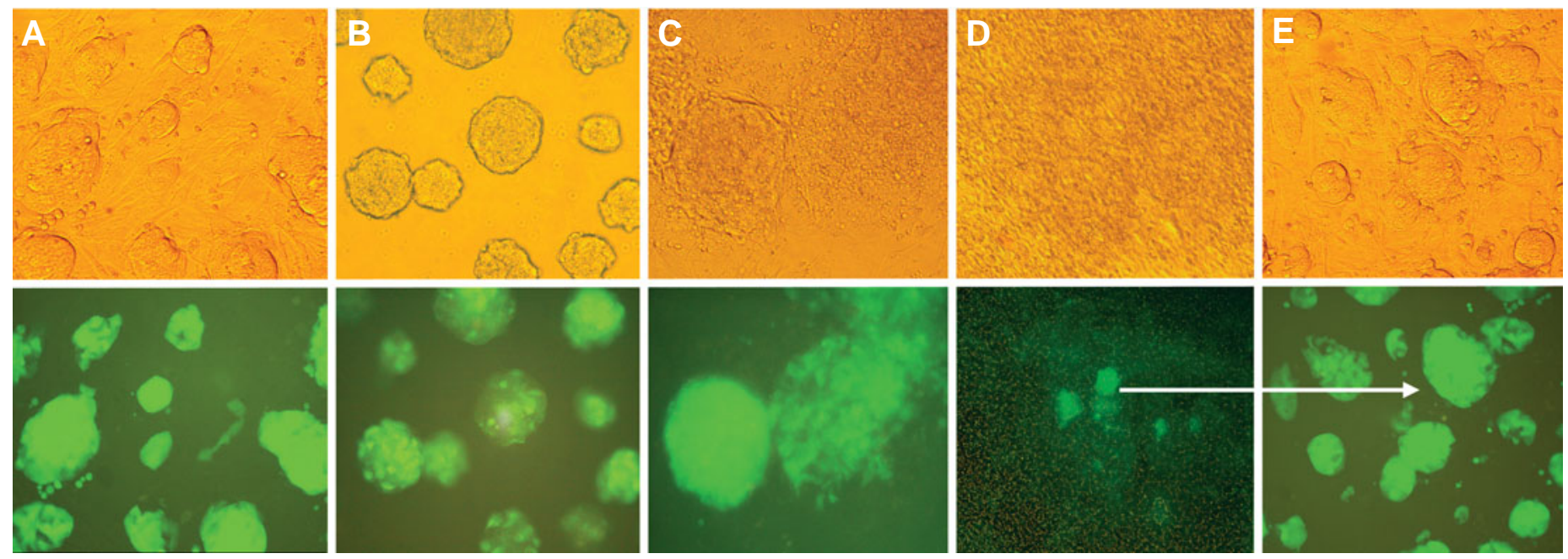

Fig. 1. Sequence of micrographs showing embryonic stem (ES) cells transformed with mTert-GFP during differentiation induced by leukemia inhibitory factor (LIF) removal. (Upper photographs were taken under light microscopy at 200x magnification and lower photographs under epifluorescence). (A) ES cell expressing green fluorescent protein (GFP); (B) four days after LIF removal, the ES cells plated in non-adherent dishes form embryoid bodies (EBs); (C) after 6 days in the absence of LIF, the EBs plated in gelatine coated tissue dishes start to differentiate into different cell types showing diminished fluorescence intensity; (D) after 12 days in the absence of LIF, EBs differentiate into monolayer cells and loose fluorescence; in some wells, groups of GFP expressing cells remain among the differentiated cell colonies; (E) these cells expressing GFP under the mTert promoter can be picked up, cultured and expanded under ES cell culture conditions, generating new ES cell-like colonies in the presence of LIF.

of cells formed monolayer of fibroblast-like cells, epithelial-like cells, cardiomyocytes and other differentiated cells and they never recovered the expression of ES cell pluripotent markers. Only in some cases we could find expression of Cx43 and Glut1.

\section{Expression of markers of pluripotency or differentiated phe- notypes}

Immunological analysis of four ES-like EB derived lines (ES-EB1 to -4$)$ showed that two markers of undifferentiated ES cells, Nanog and SSEA-1, were uniformly expressed in the ES-EB lines after culture during three passages in ES cells medium (Fig. 3)

RT-PCR was performed to assess expression of genes characteristic for ES. Bands of the appropriate size were observed for all these genes using species-specific primers; and the amplicon identities were confirmed by sequencing the PCR products. All the molecular analyses were performed on 8 of the 23 new ES-like EB derived lines (Table 1 and 2). All the pluripotency markers were detected in the transformed ES cells (R1-mTert-GFP) but after recovering the $E S$-like phenotype from differentiated $E B$, only one of the clones analyzed continued to express all the markers. Abcg2 marker was absent in 7 of the lines. Oct3/4 and Rex 1 were absent in 6 of the lines. Fgfr4 and Glut1 were absent in 3 of the lines. Interestingly, all the ES-EB lines expressed the marker Nanog and 7 of the 8 ES-EB lines analyzed expressed Foxd3. To determine whether after passages in ES cell media, the ES-EBs would be able to recover the expression of pluripotency markers, we selected the four ES-EB lines (ES-EB1-4) that had lost the expression of most of the markers. Thus, after 7-9 passages in ES cell media, the expression of most of these markers was recovered (Table 1). The only two markers that were lost in the four ES-EB lines, Oct3/4 and Rex1 were recovered in all the lines; Foxd3 was recovered in line ES-EB1; Fgfr4 was recovered in lines ES-EB1, 2 and 3; Cx43 was recovered in lines ES-EB1 and 2; and Glut1 was recovered in lines ES-EB1, 2 and 3.
Table 2 summarizes the results of our experiments using differentiation markers. GATA 2, a zinc finger transcription factor, was the only marker present in the original R1 ES cell line that was also detected in all the ES-like cells derived from EB. Different markers of differentiation were found in different ES-EB lines, indicating variation in the state of differentiation among them.
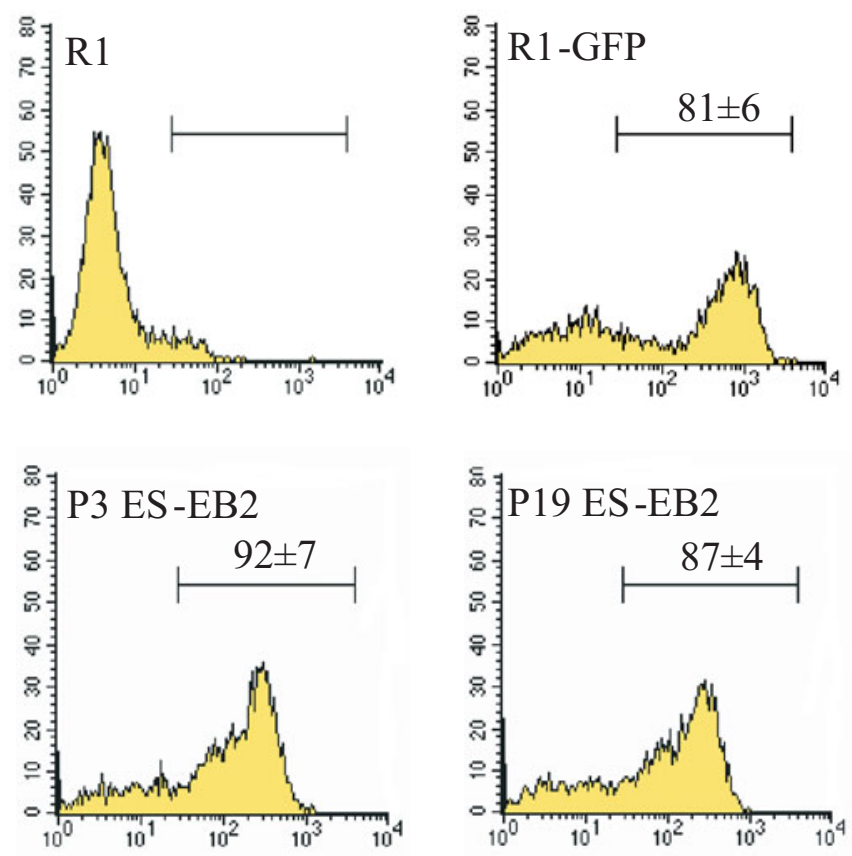

Fig. 2. FACS analysis of green fluorescent protein (GFP) expression in different passages of ES-EB cells. The percentage of cell population expressing GFP was similar between the R1-mTert-GFP ES cell line and the ES-EB lines generated (the fig shows the ES-EB2 at passage 3 and 19) 
P3 ES-EB2
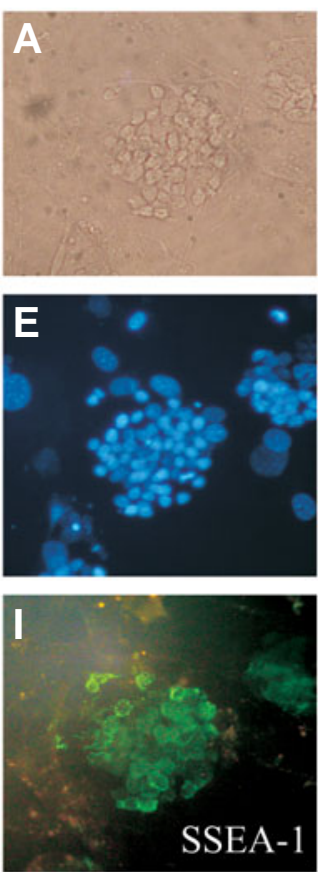

P20 ES-EB2
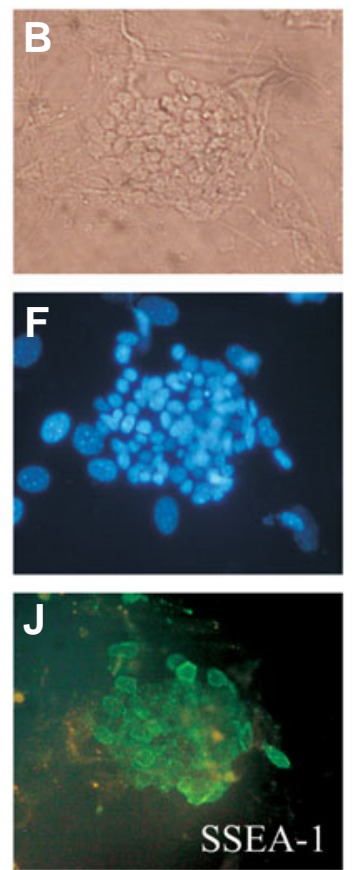

P3 ES-EB2
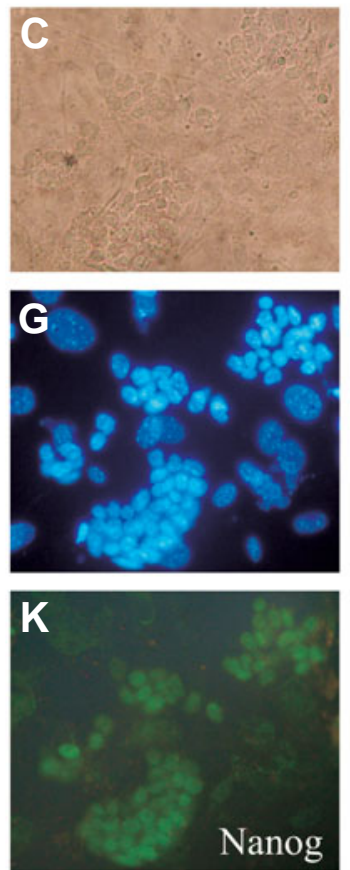

P20 ES-EB2
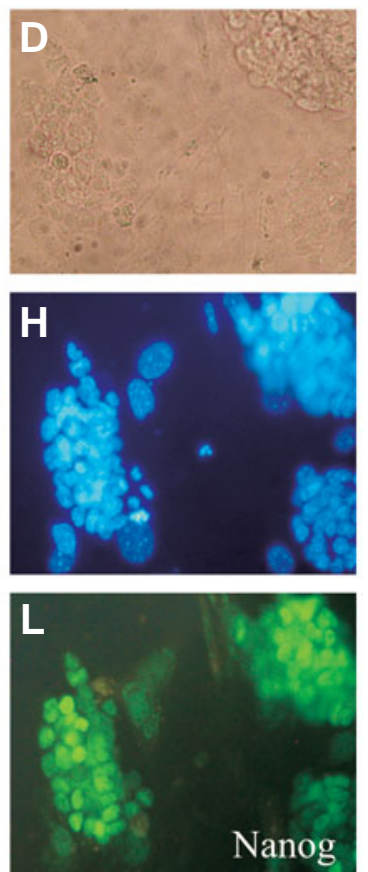

Fig. 3. Expression of Nanog and SSEA-1 in an ES-EB line at passages $\mathbf{3}$ and 20 (A,B,C,D) Phase contrast microphotographs. (E,F,G,H) Nuclear stain (DAPI). Membrane SSEA-1 immunofluorescence (I,J) and Nuclear Nanog immunofluorescence (K,L) are detected in the ES-EB line at early and late passage (200x magnification).

Terf1 and Foxd3 and line ESEB3, which initially preserved the expression of the majority of pluripotent markers except Oct-4, Rex1 and Fgfr4 (Table 1). Over 200 embryos which were injected or aggregated with every ES-EB line at early passage (2-4 passages) were transferred to recipient females, but no chimeric mice were obtained. Only line ESEB2 was able to produce 1 chimera (with less than $25 \%$ of coat colour chimerism) after the transfer of 269 blastocysts. Nevertheless, after 911 passages of these cells in ES cell media, line ES-EB2 and 3 were reassessed for their potential for chimera formation and following the transfer of 212 blastocysts from aggregation or injection with ES-EB2 line, 8 out of the 21 born alive were chimeric and following the transfer of 153 blastocysts from aggregation or injection with ES-EB3 line,

Foxa2 was expressed in 7 lines; Myf5, Krt15 and Tubb3 were expressed in 5 lines; Msx 1 was expressed in 4 lines; Gata-4 was expressed in 3 lines; and Nes and Vim were expressed in 2 lines. To determine whether after several passages in ES cell media, the ES-EBs would be able to loss the expression of differentiation markers, we studied their expression after culture in the same four ES-EB lines where pluripotency markers have been studied.(ESEB1-4) after culture in ES medium for 7-10 passages. We found that line ES-EB1, that at passage 2 expressed all the differentiation markers, lost the expression of all the markers except Gata2 and Foxa2 after 7 passages. In the other three lines analyzed, the expression of the differentiation markers that were present at passage 2 (ES-EB2: Gata-4, Msx1, Krt16, Foxa2, Nes, Vim and Tubb3; ES-EB3: Myf5, Krt15, Foxa2 and Tubb3; ES-EB4: Myf5, Krt15, Foxa2 and Tubb3) was lost after 7-10 passages in ES cell media.

Collectively, these findings indicate that some of the ES-like cells recovered from differentiated EBs were not significantly different in terms of morphology and pluripotency marker expression to R1 and to R1-mTert-GFP and were also similar to other mouse ES cell lines such as D3 (Ginis et al., 2004). Moreover, when the ES-EB lines were cultured in ES cell media for 7-9 passages, they recovered the original expression pattern of the pluripotent R1 line.

\section{Chimera formation}

Three ES-EB lines were injected into blastocysts or aggregated with eight-cell stage embryo to produce chimeras, ES-EB1 that initially lost most of the pluripotency markers, ES-EB2 that lost the majority of the markers but kept the expression of Nanog, we obtained 5 chimeric mice out of 13 born alive. The level of chimerism observed was similar to that obtained with the original R1-mTert-GFP ES line, ranging from 15 to $50 \%$ based on coat colour contribution. These results indicate that the cells had recovered the pluripotential nature of the original ES cell line. It is form chimera only after they recovered 8 of the 9 pluripotent markers. ES-EB3 at passage 2, even expressing 5 pluripotent markers, was unable to form chimeras, this ability was only recovered at passage 7 , after recuperating the expression of Oct3/4, Rex 1 and Fgfr4,. Five of the chimeric mice with the higher chimerism were assessed for germline transmission, but only one of the lines produced germline transmission after four consecutive mating.

\section{RNA expression profile of IAP and MUERV-L retrotransposable elements}

Similar expression patterns were observed for IAP and MuERV$L$ retrotransposons (Fig. 4). Expression levels were initially increased in the 4 ES-EB lines ( 1 to 4 ) that had lost most pluripotency markers (Table 1), but remained unaffected in ES-EB 8 line or less affected in ES-EB line7, which had not lost the expression of these markers. However, after 5-9 passages in ES cell media, ES-EB lines 1 to 4 showed similar levels of retrotransposable element expression than the $\mathrm{R} 1$ line. No differences in expression between R1 at passage 14, R1-mTert-GFP at passage 17 and early embryoid bodies generated from this line were observed (Fig 4), indicating that at this stage of differentiation there are no differences in IAP and MuERV-L mRNA expression. Our results suggest a possible role for IAP and MuERV-L expression in important also to point out that ES-EB2 and 3 lines were able to 
$\square$ Initial $\square$ After 9 passages
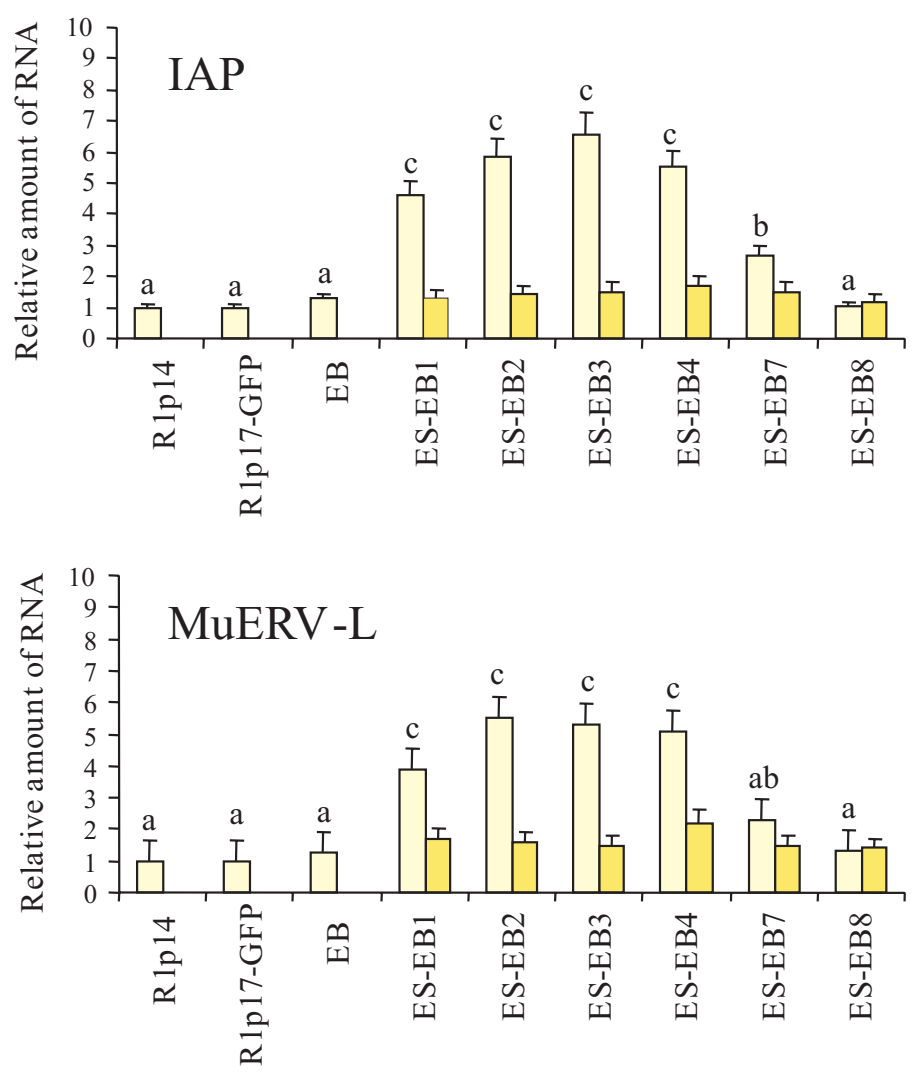

Fig. 4. Quantitative RT-PCR analysis of intracisternal-A particle (IAP) and murine endogenous retrovirus- $L$ (MuERV-L) mRNA expression. Each lane represents the mean plus standard desviation of 3 technical replicates from 3 independently prepared samples, expressed relative to the group with lowest expression. a,b,c refers to significant differences in relative transcript abundance between column $(P<0.05)$.

preserving ES cell pluripotency and differentiation capacity; however, the changes in expression pattern may be a consequence of regaining pluripotency rather than a cause. In addition, we have found that in some cells, adequate culture conditions could modulate and re-program the expression of these retrotransposons.

Methylation patterns of IAP and MuERV-L retrotransposons

For the bisulphite analysis of the methylation pattern of retrotransposon IAP, primers against the 5'LTR sequence were designed to amplify a $255 \mathrm{bp}$ fragment containing $10 \mathrm{CpG}$ dinucleotides spanning the IAP promoter (Fig. 5A), which is known to be methylation sensitive (Lane et al., 2003). A similar strategy was followed for the 5 'LTR sequence of the MuERV-L retrotransposon, allowing the amplification of a $270 \mathrm{bp}$ fragment containing $6 \mathrm{CpG}$ dinucleotides spanning its promoter (Peaston etal., 2004) (Fig. 5A). We analyzed the methylation profiles of IAP and MuERV-L repeated sequences in DNA samples obtained from $R 1$ at passage 14, R1-mTert-GFP at passage 17, early embryoid bodies generated from this line and ES-EB lines 1, 2, 3 and 8 generated from EB derived from R1-mTert-GFP ES cells. $A$ reduction on the percentage of methylation in the promoter regions of the IAP and MUERV-L transposable elements were observed in 3 of the ES-EB lines that no longer expressed most of the pluripotency markers, yet no differences were detected in the ES-EB 8 line that continued to express these markers (Fig. 5). The reduction on the percentage of methylation of the lines ESEB 1, 2 and 3 inversely correlated with the transcriptional activity of retrotransposons (Fig. 4). However, the line ES-EB3 that displayed a significant increase in the relative amount of IAP and MuERV-L mRNAs (Fig 4), did not display a significant difference in the percentage of methylation of the two retrotransposable elements. Moreover, no differences were observed after culturing in ES conditions during 9 passages (data not shown) indicating that culturing also affects the methylation status of these cells and that an appropriate culture could re-program some cells.

\section{Discussion}

One of the main targets of embryonic stem cell research is to control the differentiation of human ES cells into particular cell types, an essential requisite for their use in therapeutic transplantation, drug testing, or screening potential toxins. Understanding the mechanisms involved in the differentiation of ES cells to EBs and onto specific lineages is crucial to the safe use of ES cells in cell therapies. To date, several laboratories have demonstrated that in vitro human ES cells are pluripotent and that they can generate cell types derived from all three embryonic germ layers. However, the experimental transfer of ES cells has been related to an unusually high risk of genetic changes and tumour formation (Taupin, 2006). The potential disadvantages of the use of human ES cells for transplant therapy include the propensity of undifferentiated ES cells to induce the formation of tumours (teratoma). The genetic mechanisms by which ES cells give rise to tumours in vivoare poorly understood. It is possible that since in stem cells the machinery for self-renewal is already activated, maintaining this activation may be a simpler task than turning it on de novo. Given it is the undifferentiated cells-rather than their differentiated progeny - that seem to induce teratoma, tumour formation might therefore be avoided by devising methods of identifying and removing any undifferentiated ES cells prior to transplant (Drukker et al., 2002).

ES cells differentiated into EBs by the removal of LIF from the defined medium and then differentiated as a monolayer have been described to exhibit varied expression of marker transcripts characteristic of mesoderm, endoderm and ectoderm lineages (Ward et al., 2004). In agreement with these results, our ES-like cells derived from differentiated EB also expressed markers of differentiation characteristic of the three layers. The incomplete differentiation of ES cells is commonly observed in EB, yet there are no reports of the detection of ES-like cells in the monolayer obtained from EBs after two weeks of differentiation. Herein, we demonstrate that monolayer cells derived from EBs, which look homogeneous under the light microscope, feature a proportion of completely undifferentiated cells and that these cells can be withdrawn from the monolayer and be stimulated to recover their pluripotent state by culturing in standard ES cell media. In effect, these cells recover their capacity to express several markers of pluripotency as well as their potential to form chimeras. In addition, ES-like cells that failed to express some of these pluripotency markers retained some level of multipotency-memory that al- 
lowed them to recover the expression of the markers after several passages in ES cell culture and to regain the methylation status of some retrotransposons along with the potential to form chimeras. These findings suggest that: (1) a more specific analysis of markers is required to confirm the loss of the cells' multipotent characteristics; and (2), that adequate culture conditions may genetically reprogram cells with memory for pluripotency to produce ES cells with pluripotent properties. It should be highlighted that even cell lines that had lost the expression of Oct-4 were able to recover the expression of this marker and then recover also the potential to form chimeras. Moreover, only three markers of pluripotency (Nanog, Foxd3 and mTert) were detected in almost all the ES-EB cells, indicating that these three markers could serve to identify the inadvertent presence of pluripotent cell stages among differentiated cells.

Nanog, a homeobox transcription factor, is a pluripotent cellspecific gene that plays a crucial role in maintaining the undifferentiated state of early postimplantation embryos and ES cells. Nanog mRNA is present in pluripotent mouse and human cell lines and absent from differentiated cells (Chambers et al., 2003). Two important properties conferred by Nanog have been described: a fundamental role in pluripotency of both ICM (inner cell mass) and ES cells and an ability to maintain ES self-renewal in the absence of LIF, Oct3/4 and Stat3 (Chambers et al., 2003) (Mitsui et al., 2003). Our results agree with the importance of Nanog as a master transcriptional organizer and suggest that even in Oct4 absence, Tert, Foxd3 and Nanog may control different but partly overlapping pools of target genes. Foxd3 is a fork-head transcription factor highly expressed in mouse ES cells. In agreement with our results, it has been recently published that Oct4, Nanog and Foxd3 form a loop anchors an interdependent network of transcription factors that regulate stem cell pluripotency (Pan et al., 2006). The authors report that Nanog and Foxd3 were able to activate Oct4 promoter. The ectopic expression of $\mathrm{mTert}$ in mouse ES cells does not affect differentiation but confers resistance to differentiation- and stress-induced p53-dependent apoptosis (Lee et al., 2005). These recent data suggest that the decreased telomerase activity observed during differentiation is a consequence of the differentiation process, during which the pluripotency of the ES cell is lost. It has been demonstrated that over-expression of telomerase confers a growth advantage, stress resistance and enhanced differentiation of ES cells towards the hematopoietic linage (Armstrong et al., 2005). We propose two alternative events occurring during our differentiation protocol: first, that the mTert-GFP positive cells that we selected after two weeks of differentiation still retained some pluripotency potential; or second that the mTert-GFP positive cells recovered have no pluripotency characteristics, yet after incubation under ES cell culture conditions they recover Nanog expression and as a consequence they may recover the expression of other pluripotency markers. Whichever the case, by selecting mTert-GFP positive cells, we were able to identify the cells with a level of multipotency or of memory factors (or epi-memory factors) sufficient for them to recover their pluripotency. The combination of both markers, mTert (survival enzyme marker) and Nanog and Foxd3 (pluripotency control marker) may be useful for defining ES cell identity.

In the adult, stem cells persist in some tissues such as hematopoietic, gastrointestinal and testicular tissue and the integumentary system and carry out lifelong processes of regeneration and renewal. A recent study has reported that skinderived adult stem cells are capable of recalling the program for differentiating into an oocyte (Dyce et al., 2006). It has been suggested that the differentiation of adult stem cells is incomplete and lacks certain cues necessary to acquire a truly functional status (Belema Bedada et al., 2005), such that the multipotency potential observed for spermatogonial stem cells or skin cells may actually be imposed by the culture conditions rather than reflect the natural behaviour of a stem cell in a given niche. Just as stem cells depend on their environment to maintain their properties, the culture environment may also modulate the stem cell properties of cells with some degree of multipotency. In our experiments, due
A

IAP

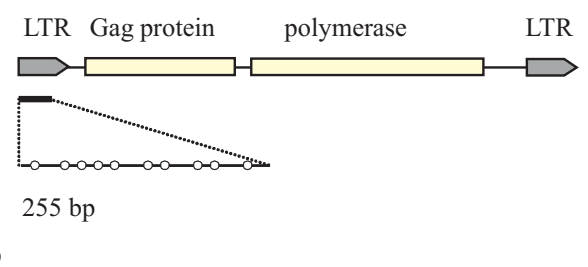

IAP

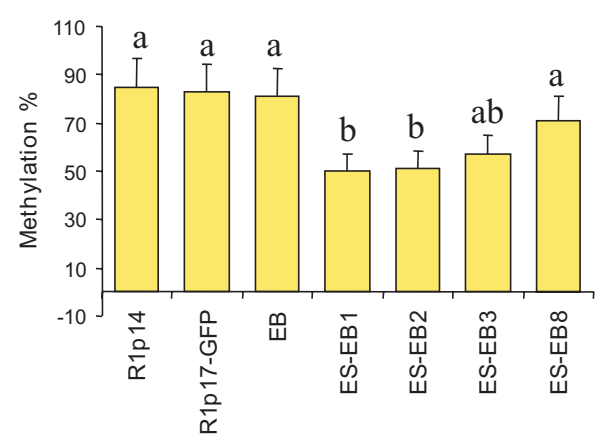

MuERV-L

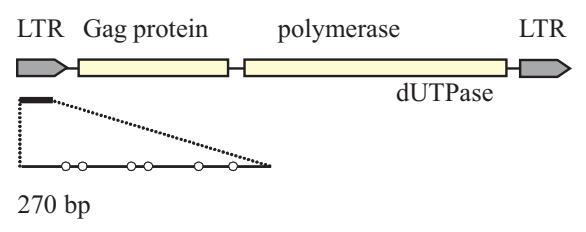

MuERV-L

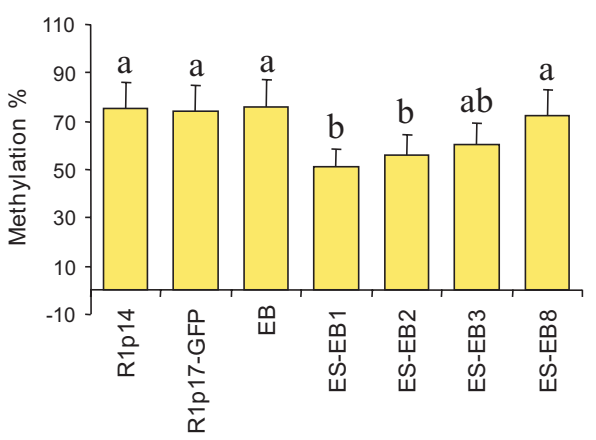

Fig. 5. Methylation profiles of two retrotransposable elements, intracisternal-A particle (IAP) and murine endogenous retrovirus-L (MuERV-L) in R1p14, R1-mTert-GFPp17, embryoid bodies and in ES-EB1, 2, 3 and 8 (at passage 3). (A) Regions analyzed by bisulphite sequencing in IAP and MuERV-L. LTR, long terminal repeat. Circles represent $C p G$ dinucleotides present in the regions analyzed. (B) Average of percentage DNA methylation following bisulphite treatment and amplification of ES cell DNA. a,b refer to significant differences in percentage of methylation between column $(P<0.05)$. 
to the specific culture conditions, ES-EB cells acquired the remarkable potential to turn on a large variety of markers specific for ES cells, such as Oct-4. The epigenetic state of the ES cell genome is extremely unstable (Humpherys et al., 2001). Accordingly, it has been established that Oct-4 gene expression is regulated by an epigenetic mechanism involving DNA methylation and the remodelling of chromatin structure (Hattori et al., 2004). Oct-4 is expressed in pluripotent cells of the embryo, in all testicular germ cell tumours (Gidekel et al., 2003), in pre-meiotic germ cells and in cell lines derived from those cells (ES and embryonic germ cells). Recently, however, the robust expression of Oct-4 and other markers of pluripotency, such as Nanog and Rex1, has also been observed in mesenchymal stem cells derived from bone marrow (Belema Bedada et al., 2005). Moreover, Dyce et al., (2006) have reported that Oct-4 is also expressed in skin sphere cells, although expression could have been turned on during the process of culturing these cells, as suggested by a study using an Oct4-GFP transgene (Kues et al., 2005). Our results suggest that any adult or foetal stem cell that has a multipotent memory may be reprogrammed by culturing to acquire in vitro pluripotency characteristics similar to those of ES cells.

Because ES cells offer an enormous potential for cell therapies, any progress in understanding the epigenetic properties of stem cells, will be crucial for their eventual safe application, to ensure that differentiated cells that are derived from ES cells are lineage-restricted and have shut down alternative options before engraftment. Recent studies have implicated retrotransposable elements in imprinting and $\mathrm{X}$-chromosome inactivation and in the developmental regulation of gene expression (Slotkin and Martienssen, 2007). Retrotransposons could be an epigeneticmarker for the characterization of the epigenetic stages of cells from pluripotent to terminal differentiation stages and could be very practical to putting ES cells into safe practical use. We do not know if some differentiated cell derived from human ES cells lines retaining this mice ES cells capacity to regain pluripotency. However, transplanting even a small number of incompletely differentiated cells represents a serious risk of including cells with tumour-forming properties into patients. In summary, our findings suggest that cells with a genetic or epigenetic memory of a multipotent development stage, can be reprogrammed to confer an ES-like pluripotency stage (with a capacity for chimera production). The implications of these findings are that before we can consider that we have obtained a homogeneous monolayer of differentiated cells for cell therapy purposes, the presence of specific pluripotency markers should be checked for, to avoid the possible transfer of a significant proportion of undifferentiated cells with tumourogenic properties.

\section{Materials and Methods}

\section{Reagents and media}

Unless otherwise stated, all chemicals and media were purchased from Sigma Chemical Co. (Madrid, Spain).

\section{Culture, transformation and differentiation of ES cells}

Undifferentiated mouse ES cells (R1 from A. Nagy lab) were maintained on mitomycin-C treated (Sigma-Aldrich corporation St. Louis, MO, USA) mouse embryonic fibroblast (MEF) cells on $0.1 \%$ gelatine coated tissue plates in Dulbecco's modified Eagle medium (DMEM plus 4500 mg/
I glucose, glutaMAX and pyruvate; Invitrogen, Carlsbad, CA, USA) supplemented with $20 \%$ FBS (PAA Laboratories Cölbe Germany), 2 mM glutamine, $1 \mathrm{mM}$ MEM nonessential amino acids solution, $1 \mathrm{mM} \beta$ mercaptoethanol, $1000 \mathrm{U} / \mathrm{ml} \mathrm{LIF}$ and an antibiotic mixture containing 100 $\mathrm{U} / \mathrm{ml}$ penicillin and $100 \mu \mathrm{g} / \mathrm{ml}$ streptomycin (Pericuesta et al., 2006).

A 4,471 bp fragment of the mouse telomerase reverse transcriptase promoter (mTert) (NCBI GenBank; accession number AF 121949) located upstream from the first ATG of the mTert gene open reading frame, was amplified by PCR and ligated to pEGFP (Clontech Laboratories, Inc., Palo Alto, CA, USA) to promote the expression of GFP (Pericuesta et al., 2006). Ten micrograms of the linearized mTert-GFP construct were electroporated into $3 \times 10^{6}$ cells using a Multiporator (Eppendorf, Hamburg, Germany) and a pulse of $300 \mathrm{~V}$ for $500 \mu \mathrm{s}$. Cells were allowed to recover for $24 \mathrm{~h}$ before $\mathrm{G} 418$ was added to give a final concentration of $150 \mu \mathrm{g} / \mathrm{ml}$. Cellular clones were selected by geneticin resistance over 7 days, replacing the selection medium every day. Clones were harvested by trypsinization and allowed to attach onto the wells of 96 -well plates forming cell clusters, which were maintained for 2 days in LIF-supplemented medium until colonies formed. Transgene integration was confirmed by GFP PCR (Gutierrez-Adan and Pintado, 2000).

GFP PCR was performed using the primers GFP-1 (5'-TGA ACC GCA TCG AGC TGA AGG G-3') and GFP-2 (5'-TCC AGC AGG ACC ATG TGA TCG C-3'), specifically amplifying a 340 bp portion of GFP DNA. Amplification was carried out in a total volume of $25 \mu \mathrm{l}$ ( $1 \times$ of PCR mix containing $1 U$ Taq polymerase, $2.5 \mu \mathrm{l} 10 \mathrm{x}$ buffer, both from Promega, $100 \mu \mathrm{M}$ each dNTP, $0.1 \mu \mathrm{M}$ each primer and $2.5 \mathrm{mM} \mathrm{MgCl}_{2}$ ). Samples were loaded directly from ice onto the heating block at $92^{\circ} \mathrm{C}$ to minimize the time required to reach denaturation temperature. The PCR protocol was an initial step of $92^{\circ} \mathrm{C}(2 \mathrm{~min})$, followed by 32 cycles of $92^{\circ} \mathrm{C}(30 \mathrm{~s}), 59^{\circ} \mathrm{C}(30$ s) and $72^{\circ} \mathrm{C}(30 \mathrm{~s})$ and a final extension cycle at $72^{\circ} \mathrm{C}(10 \mathrm{~min})$. PCR products were resolved on $1.5 \%$ TBE agarose gels, followed by staining with ethidium bromide and visualized using UV light.

\section{Recovering ES cells from differentiated EBs. Chimera formation}

To initiate differentiation, ES cells were trypsinized and back-plated for 15 minutes to deplete fibroblasts and then plated in non-adherent $10 \mathrm{~cm}$ bacterial-grade Petri dishes $\left(5 \times 10^{5}\right.$ cells per dish) in ES medium without LIF. Embryoid bodies were collected after four days using a yellow pipette tip and transfer to $0.1 \%$ gelatine coated tissue plates in ES medium without LIF to allow EBs differentiation into different cell types. Medium was replaced every day. After 12 days in the absence of LIF, the EBs differentiate into monolayer cells attached to the culture dish, but some small groups of green cells, expressing the transgenic GFP under the mTert promoter, could be identified under the fluorescent microscope among the cells forming the monolayer. These groups of cells (denoted ES-EB) and some groups of cells that did not express GFP (control group), were picked up using a $2 \mu \mathrm{l}$ pipette tip (before lifting the cells, the monolayer cells around the clumps of green cells were cut using the pipette tip). The clumps were transferred to a tissue plate with mitomycin$\mathrm{C}$ treated MEF and cultured and expanded under ES cells culture conditions with LIF as described above.

For chimera formation, we used blastocyst ES cell injection and eightcell stage embryo aggregation procedures. For the first method, cells were injected into the blastocoel of $3.5 \mathrm{dpc}$ blastocysts of CD1 mice using Eppendorf micromanipulators (Eppendorf TransferMan NK 2, Hamburg, Germany). The blastocysts were returned to the oviducts of $0.5 \mathrm{dpc}$ pseudopregnant CD1 foster mothers on the day of microinjection. In the second procedure, ES-cell derived embryos were generated by aggregating clumps of ES cells (8-15 cells in each) with individual eight-cell embryos. ES cell:embryo aggregates were cultured overnight in KSOM + $4 \%$ ES cells medium described above and the following morning, the majority of the aggregates formed blastocysts and were transferred to the oviduct of pseudo-pregnant surrogate mothers. To analyzed chimerism, the embryos were allowed to develop to term and chimerism was tested by coat color compared with the white colour of the recipient strain. Mice 


\section{SUPPLEMENTARY TABLE 1}

\section{PRIMERS USED FOR THE RT-PCR OF GENES ASSOCIATED WITH DIFFERENTIATED AND UNDIFFERENTIATED ES CELL STATES}

\begin{tabular}{|c|c|c|c|c|}
\hline Gene symbol & MGI Official name & Primer 5'-3' (Forward/Reverse) & Size & UniGene \\
\hline Gata-4 & GATA binding protein 4 & $\begin{array}{l}\text { GCCTGTATGTAATGCCTGCG/ } \\
\text { CCGAGCAGGAATTTGAAGAGG }\end{array}$ & 469 & Mm. 24766؟ \\
\hline Gata-2 & GATA binding protein 2 & $\begin{array}{l}\text { ACCCACGCCACCCAAAGAAGTG/ } \\
\text { GCCGCCTTCCATCTTCATGCTC }\end{array}$ & 157 & Mm. 272747 \\
\hline Afp & Alpha fetoprotein & $\begin{array}{l}\text { TTTTCTGAGGGATGAAACCTATG/ } \\
\text { AAGCTCTTGTTTCATGGTCTGTA }\end{array}$ & 116 & Mm. $35857 \mathrm{C}$ \\
\hline Msx1 & Homeo box, msh-like 1 & $\begin{array}{l}\text { GCTATGACTTCTTTGCCACTCG/ } \\
\text { TTAAGAGAAGGGGACCAGGTGG }\end{array}$ & 1016 & Mm. 25912 \\
\hline $\mathrm{T}$ & Brachyury & $\begin{array}{l}\text { GCTGTGACTGCCTACCAGCAGAATG/ } \\
\text { GAGAGAGAGCGAGCCTCCAAAC }\end{array}$ & 220 & Mm. 913 \\
\hline Myf5 & Myogenic factor 5 & $\begin{array}{l}\text { TGCCATCCGCTACATTGAGAG/ } \\
\text { CCGGGGTAGCAGGCTGTGAGTTG }\end{array}$ & 352 & Mm. 4984 \\
\hline Krt15 & Keratin 15 & $\begin{array}{l}\text { CACCACATTCTTGCAAAC/ } \\
\text { ATTAAGGTTCTGCATGGTC }\end{array}$ & 313 & Mm. 38498 \\
\hline Foxa2 & Forkhead box A2 & $\begin{array}{l}\text { GGACGTAAAGGAAGGGACTCCAC/ } \\
\text { AGCCCATTTGAATAATCAGCTCAC }\end{array}$ & 174 & Mm. 938 \\
\hline Nes & Nestin & $\begin{array}{l}\text { AGTGTGAAGGCAAAGATAGC/ } \\
\text { TCTGTCAGGATTGGGATGGG }\end{array}$ & 316 & Mm. 23742 \\
\hline Vim & Vimentin & $\begin{array}{l}\text { AAGGGTGAGTAGAGAGTTC/ } \\
\text { AACACTGTTAGGAAAGAGG }\end{array}$ & 222 & Mm. 7 \\
\hline Tubb3 & Tubulin, beta 3 & $\begin{array}{l}\text { TCACTGTGCCTGAACTTACC/ } \\
\text { GGAACATAGCCGTAAACTGC }\end{array}$ & 318 & Mm. 40068 \\
\hline Nanog & Nanog homeobox & $\begin{array}{l}\text { AGGGTCTGCTACTGAGATGCTCTG/ } \\
\text { CAACCACTGGTTTTTCTGCCACCG }\end{array}$ & 363 & Mm. 6047 \\
\hline Oct3/4 (Pou5f1) & $\begin{array}{l}\text { POU domain, class } 5 \text {, } \\
\text { transcription factor } 1\end{array}$ & $\begin{array}{l}\text { GGAGAGGTGAAACCGTCCCTAGG/ } \\
\text { AGAGGAGGTTCCCTCTGAGTTGC }\end{array}$ & 391 & Mm. 17031 \\
\hline $\operatorname{Rex1}(\mathrm{Zfp} 42)$ & Zinc finger protein 42 & $\begin{array}{l}\text { CCAGGGAAGGATGAGAGA/ } \\
\text { TAGAAGCTGGTAACAGGGAG }\end{array}$ & 264 & Mm. 285848 \\
\hline Foxd3 & Forkhead box D3 & $\begin{array}{l}\text { TCTTACATCGCGCTCATCAC/ } \\
\text { TCTTGACGAAGCAGTCGTTG }\end{array}$ & 171 & Mm. 4758 \\
\hline Fgfr4 & Fibroblast growth factor receptor 4 & $\begin{array}{l}\text { TCCGACAAGGATTTGGCAG/ } \\
\text { GCACTTCCGAGACTCCAGATAC }\end{array}$ & 400 & Mm. 4912 \\
\hline Terf1 & Telomeric repeat binding factor 1 & $\begin{array}{l}\text { TTCAACAACCGAACAAGTGTC/ } \\
\text { TCTCTTTCTCTTCССССTCC }\end{array}$ & 215 & Mm. 4306 \\
\hline Cx43 (Gja1) & $\begin{array}{l}\text { Gap junction membrane channel } \\
\text { protein alpha } 1\end{array}$ & $\begin{array}{l}\text { TACCACGCCACCACTGGCCCA/ } \\
\text { ATTCTGGTTGTCGTCGGGGAAATC }\end{array}$ & 290 & Mm. 4504 \\
\hline Glut1 (Slc2a1) & $\begin{array}{l}\text { Solute carrier family } 2 \text { (facilitated } \\
\text { glucose transporter), member } 1\end{array}$ & $\begin{array}{l}\text { CAGTCAGCAATGAAGTCCAG/ } \\
\text { AGCAGTAAGTTCTCAGCCTC }\end{array}$ & 585 & Mm. 30044 \\
\hline Abcg2 & $\begin{array}{l}\text { ATP-binding cassette, sub-family G } \\
\text { (WHITE), member } 2\end{array}$ & $\begin{array}{l}\text { CCATAGCCACAGGCCAAAGT/ } \\
\text { GGGCCACATGATTCTTCCAC }\end{array}$ & 326 & Mm.196728 \\
\hline Gapdh & $\begin{array}{l}\text { Glyceraldehyde-3-phosphate } \\
\text { dehydrogenase }\end{array}$ & $\begin{array}{l}\text { GGGTGTGAACCACGAGAAATATGA/ } \\
\text { CСTTCCACAATGCCAAAGT }\end{array}$ & 250 & Mm.379644 \\
\hline
\end{tabular}

that did not show coat color chimerism were killed at 21 days old and DNA prepared and processed for PCR and Southern blot analysis to identify GFP integration using standard protocols.

\section{FACS analysis}

To analyze the proportion of cells expression GFP in ES-EBs cell lines at different passes, cell were detached with trypsin and washing with PBS, then cells were resuspended at a final concentration of $10^{6} \mathrm{cells} / \mathrm{ml}$ in PBS and analyzed for flow cytometry. R1 and R1-mTert-GFP cells were used as controls. Flow cytometry analysis was performed using a FACSCalibur System and CellQuest software.

\section{Karyotype analysis}

Chromosome spreads of the ES cell lines were performed as described below. ES cells were arrested in metaphase by supplementing the culture medium with $0.1 \mu \mathrm{g} / \mathrm{ml}$ colcemid for $4 \mathrm{hr}$ at $37^{\circ} \mathrm{C}$ in a $5 \% \mathrm{CO}_{2}$ air atmosphere. Posteriorly cells were treated with trypsin-EDTA for 2 min at $37^{\circ} \mathrm{C}$. After pipeting, the single cell suspension was washed twice with PBS by centrifugation at $200 \mathrm{G}$ for $5 \mathrm{~min}$. The pellet obtained was exposed to a hypotonic stock by resuspension in $0.075 \mathrm{M} \mathrm{KCl}$ for $15 \mathrm{~min}$ at $37^{\circ} \mathrm{C}$. After a second centrifugation step the hypotonic solution was removed and the pellet fixed with a methanol/acetic acid solution $(3: 1 ; \mathrm{vol} / \mathrm{vol})$ by gently pipetting. Ten min later, cells were pelleted again and fixed a second time. Before slide mounting, cells were washed twice with PBS. The slides were dried overnight at $55^{\circ} \mathrm{C}$, stained in freshly made $10 \%$ Giemsa solution for $30 \mathrm{~min}$ and rinsed with distilled water. Finally, airdried slides were observed under microscope. Chromosome number was obtained after analyzing at least 30 metaphase cells for each cell preparation.

\section{Analysis of marker gene expression by RT-PCR}

Total RNA was extracted from ES cell pellets using the Ultraspect ${ }^{\mathrm{TM}}$ RNA Isolation System (Biotecx Lab. Inc., Houston, Texas, USA) according to the manufacturer's instructions. Precipitated RNA was dissolved in DEPC-treated water and digested with $1 \mathrm{U}$ of RQ DNase I (Promega) at $37^{\circ} \mathrm{C}$ for $20 \mathrm{~min}$ to ensure that the only source of DNA in the PCR was cDNA to cellular RNA. Finally, the RNA was extracted by phenol purification and ethanol precipitation, reconstituted in $50 \mu \mathrm{l}$ of DEPC-treated 
water and stored at $-70^{\circ} \mathrm{C}$ until RT-PCR.

The RT reaction was performed following the manufacturer's instructions (Jimenez et al., 2003) (Gibco-BRL, Grand Island, NY, USA). Five micrograms of RNA were dissolved in water, heat-denatured $\left(65^{\circ} \mathrm{C}, 2\right.$ $\mathrm{min}$ ) and reverse-transcribed at $37^{\circ} \mathrm{C}$ for $60 \mathrm{~min}$ in a final volume of $20 \mu \mathrm{l}$ containing $0.5 \mathrm{mM}$ of each dNTP, $0.2 \mu \mathrm{M}$ oligo (dT) $0,5 \mu \mathrm{M}$ of random primers, MMLV-RT $(0.5 \mu \mathrm{l})$, RNasin $(0.2 \mu \mathrm{l}), 1 \times$ MMLV-RT buffer with 8 mM DTT. After reverse transcription, different genes were PCR amplified by adding a $1.5 \mu \mathrm{l}$ aliquot of each sample to the PCR mix containing the specific primers. The PCR products were subjected to electrophoresis on $2 \%$ agarose gel. The primers used for RT-PCR are listed in Supplementary Table 1. Gapdh was used as a positive control and the absence of genomic contamination was systematically checked with Gapdh amplification of the RNA samples without reverse transcriptase. In addition, amplicon identities were confirmed by sequencing the PCR products. Generation of the expected fragments was strictly dependent on the presence of RNA in the RT reaction. Genes previously reported as markers of early differentiation into germ layers or into tissue-specific precursors were chosen as sensitive indicators of differentiation. The quality of the ES-like cells recovered from differentiated EBs was confirmed by evaluating several markers expressed by undifferentiated and differentiated ES cells (Ginis et al., 2004, Thomson et al., 1998). We explored the expression of a set of markers characteristic of pluripotent cells and previously reported to be associated with the pluripotent state: Nanog (Chambers et al., 2003, Mitsui et al., 2003), Oct3/4 (Okamoto et al., 1990) and Rex1 (Ben-Shushan et al., 1998). Amplicon sequencing confirmed the amplification of the correct mRNA and not other pseudo- or retro-genes. We also determined markers expressed in undifferentiated cells that are controlled by the OCT3/4 and SOX-2 genes: Foxd3 (Sutton et al., 1996), Fgfr4 (McDonald and Heath, 1994) and telomerase repeat binding factor Terf1 (Broccoli et al., 1997). In addition, the expression of other markers present on blastocysts or other stem cell populations such as the gap junction membrane channel protein alpha 1, Cx43 (Rizos et al., 2002), soluble carrier family 2 -facilitated glucose transporter- member 1 , Glut1 (Morita et al., 1994) and ATP-binding cassette, sub-family G white- member 2, Abcg2 (Lu et al., 2002) were also examined. Besides trying to identify a set of ES cell-specific markers, we also used a set of markers to assess the state of differentiation of our ES-like cell lines. Thus, to analyze the expression of markers characteristic of differentiated phenotypes we used published RT-PCR primers that amplify genes characteristic of endoderm (Gata-4, Gata-2, Afp, Foxa2), mesoderm (Msx1, T, Myf5, Krt15) and ectoderm (Nes, Vim and Tubb3) lineages.

\section{Immunocytochemistry}

All the procedures were done at room temperatre. For Nanog detection cells were fixed with $4 \%$ paraformaldehyde for $20 \mathrm{~min}$ and they were permeated with PBS $/ 0,1 \%$ Triton X-100 (PBST). After that, cells were incubated for 30 min with Signal Enhancer (Chemicon International, Inc., Temecula, CA), then cells were blocked for $1 \mathrm{~h}$ with PBST/5\% BSA and then incubated $2 \mathrm{~h}$ with primary antibody Nanog (Chemicon) at 1:100 working dilution. For SSEA-1 detection cell were first fixed with $4 \%$ paraformaldehyde for $10 \mathrm{~min}$. After incubation for $30 \mathrm{~min}$ with Signal Enhancer (Chemicon), the cells were blocked for $1 \mathrm{~h}$ at PBS $/ 5 \% \mathrm{BSA}$ and incubated for $2 \mathrm{~h}$ with the primary antibody SSEA-1 (Chemicon) at 1:100 working dilution. After three washes in PBS, fluorescent secondary antibodies Alexas 488 (Chemicon) at 1:500 dilution in PBS were incubated with cells for $1 \mathrm{~h}$ to detect expression. Nuclear staining was performed with DAPI (Sigma). The slides were mounted with Vectashield (Vector, Burlingam, CA).

\section{Quantifying mRNA expression of IAP and MuERV-L by real-time RT- PCR}

RNA isolation and reverse-transcription procedures were performed as described above. The primers used are provided in Supplementary table 2 (Ramirez et al., 2006). For quantification of mRNA transcription of
intracisternal-A particle (IAP) and murine endogenous retrovirus- $L$ (MuERV-L elements), RT was performed using random primers and oligo dT. Relative transcript amounts were quantified by real time quantitative RT-PCR (qRT-PCR) in three replicate PCR experiments. PCR was performed using a Rotorgene 2000 Real Time Cycler ${ }^{T M}$ (Corbett Research, Sydney, Australia) and SYBR Green (Molecular Probes, Eugene, $\mathrm{OR})$ as a double-stranded DNA-specific fluorescent dye. The PCR reaction mixture $(25 \mu \mathrm{l})$ contained $2.5 \mu \mathrm{l} 10 \mathrm{x}$ buffer, $3 \mathrm{mM} \mathrm{MgCl}_{2}$, $2 \mathrm{U}$ Taq Express (MWGAG Biotech, Ebersberg, Germany), $100 \mu \mathrm{M}$ of each dNTP and $0.2 \mu \mathrm{M}$ of each primer. In addition, the double-stranded DNA dye, SYBR Green I (1:3000 of 10000x stock solution), was included in each reaction. Details of the qRT-PCR procedure have been described elsewhere (Lonergan et al., 2003). The PCR protocol included an initial step of $94^{\circ} \mathrm{C}(2 \mathrm{~min})$, followed by 40 cycles of $94^{\circ} \mathrm{C}(15 \mathrm{~s}), 56^{\circ} \mathrm{C}(30 \mathrm{~s})$ and $72^{\circ} \mathrm{C}$ (30 s). Fluorescent data were acquired at $85^{\circ} \mathrm{C}$. The melting protocol consisted of holding at $40^{\circ} \mathrm{C}$ for $60 \mathrm{~s}$ and then heating from 50 to $94^{\circ} \mathrm{C}$, holding at each temperature for $5 \mathrm{~s}$ while monitoring fluorescence. Product identity was confirmed by ethidium bromide-stained $2 \%$ agarose gel electrophoresis. In addition, amplicon identities were confirmed by sequencing the PCR products. As negative controls, we always prepared tubes in which RNA or reverse transcriptase was omitted during the RTreaction.

The comparative CT method was used to quantify expression levels (Fernandez-Gonzalez et al., 2004). Quantification was normalized to the endogenous control GAPDH. Fluorescence was acquired in each cycle to determine the threshold cycle or the cycle during the log-linear phase of the reaction at which fluorescence increased above background for each sample. Within this region of the amplification curve, a difference of one cycle is equivalent to doubling of the amplified PCR product. According to the comparative CT method, the $\triangle \mathrm{CT}$ value was determined by subtracting the GAPDH CT value for each sample from each gene CT value of the sample. Calculation of $\Delta \Delta \mathrm{CT}$ involved using the highest sample $\Delta \mathrm{CT}$ value (i.e., the sample with the lowest target expression) as an arbitrary constant to subtract from all other $\Delta C T$ sample values. Fold changes in the relative gene expression of the target were determined using the formula $2-\Delta \Delta \mathrm{CT}$. Data on mRNA expression were analyzed using the SigmaStat (Jandel Scientific, San Rafael, CA) software package. Oneway repeated-measures ANOVA (followed by multiple pair-wise comparisons using Student-Newman-Kleus method) were used for the analysis of differences in mRNA expression assayed by quantitative RT-PCR.

\section{Bisulphite analysis of ES-EB cells}

DNA from cells was extracted according to standard proteinase $K$ digestion and phenol-chloroform extraction procedures. The isolated DNA was treated with sodium bisulphite using the EZ DNA Methylation Kit (Zymo Research, Orange, CA, USA). Bisulphite-modified DNA was amplified by PCR. The methylated status of IAP LTRs (accession M17551) was examined using the following primers:

IAP-F1: 5'-TTGATAGTTGTGTTTTAAGTGGTAAATAAA;

IAP-R1: 5'-CAAAAAAAACACCACAAACCAAAAT;

IAP-F2: 5'-TTGTGTTTTAAGTG GTAAATAAATAATTTG;

IAP-R2: 5'- AAAACACCACAAACCAAAATCTTCTAC. PCR conditions were: 1st PCR (30 cycles) F1/R1; 2nd PCR (30 cycles): F2/R2. Temperature conditions were: $94^{\circ} \mathrm{C}, 3 \mathrm{~min} ; 94^{\circ} \mathrm{C}, 20 \mathrm{~s} ; 55^{\circ} \mathrm{C}, 30 \mathrm{~s}$ (2nd PCR, $\left.60^{\circ} \mathrm{C}\right) ; 72^{\circ} \mathrm{C}, 30 \mathrm{~s} ; 72^{\circ} \mathrm{C}, 5 \mathrm{~min}$. The methylated status of MuERV-

\section{SUPPLEMENTARY TABLE 2}

\section{PRIMERS USED FOR REAL TIME PCR (QRT-PCR) OF IAP AND MUERV-L}

\begin{tabular}{llc} 
Transposon & Primer $\mathbf{5}^{\prime} \mathbf{- 3}^{\prime}$ & $\left.\mathbf{T m}^{\mathbf{*}} \mathbf{(}^{-} \mathbf{C}\right)$ \\
\hline IAP-PCR-F1 & GGGTATTGTTGAGCGTGCGC & 56 \\
IAP-PCR-R2 & TCGGGTGAGTCTTTCTGGTAC & 56 \\
MuERV-PCR-F1 & TGCTTGGGCTCAGCAACATGG & 56 \\
MuERV-PCR-R2 & GACAGAATGCCTCATCTATCGT & 56 \\
\hline
\end{tabular}


L LTRs (accession AC166650) was examined using the following primers:

RVL-F1: 5'-GTTATTATGTGATTTGAATTA;

RVL-R1: 5'-ACATACAAAACCATCAATAAAC;

RVL-F2: 5'-TTTATTATGAGTTGGGTAT;

RVL-R2: 5'-ATAAACCAAACTC TAATCTTC. PCR conditions were: 1st PCR (30 cycles) F1/R1; 2nd PCR (30 cycles): F2/R2. Temperature conditions were: $94^{\circ} \mathrm{C} 3 \mathrm{~min}, 94^{\circ} \mathrm{C} 20 \mathrm{~s}, 53^{\circ} \mathrm{C} 30 \mathrm{~s}$ (2nd PCR $60^{\circ} \mathrm{C}$ ), $72^{\circ} \mathrm{C}$ $30 \mathrm{~s}, 72^{\circ} \mathrm{C} 5 \mathrm{~min}$. PCR products were gel-purified using the ELU-QUIK DNA purification kit (Schleicher\&Schuell, Dassel, Germany) and transformed into XL1 Escherichia colicells. Positive clones were verified by restriction analysis and the products were sequenced using standard methods. Methylation percentages were obtained for each individual clone within a sample (number of methylated $\mathrm{CpG}$ ser clone divided by the total number of CpGs per clone). These values were then used to calculate the overall methylation level and standard error of the mean of each sample. A logistical regression test from the SigmaStat statistical package was used to test for differences between samples. The samples are considered significantly different when $\mathrm{P}<0.05$.

\section{Acknowledgments}

This work was supported by Grants AGL2006-04799 and AGL2004-00332 from the Spanish Ministry of Education and Science.

\section{References}

ALBANELL, J., HAN, W., MELLADO, B., GUNAWARDANE, R., SCHER, H.I., DMITROVSKY, E. and MOORE, M.A. (1996). Telomerase activity is repressed during differentiation of maturation-sensitive but not resistant human tumor cell lines. Cancer Res 56: 1503-8.

ARMSTRONG, L., LAKO, M., LINCOLN, J., CAIRNS, P.M. and HOLE, N. (2000). Mtert expression correlates with telomerase activity during the differentiation of murine embryonic stem cells. Mech Dev 97: 109-16.

ARMSTRONG, L., SARETZKI, G., PETERS, H., WAPPLER, I., EVANS, J., HOLE, N., VON ZGLINICKI, T. and LAKO, M. (2005). Overexpression of telomerase confers growth advantage, stress resistance and enhanced differentiation of escs toward the hematopoietic lineage. Stem Cells 23: 516-29.

BELEMA BEDADA, F., TECHNAU, A., EBELT, H., SCHULZE, M. and BRAUN, T. (2005). Activation of myogenic differentiation pathways in adult bone marrowderived stem cells. Mol Cell Bio/25: 9509-19.

BEN-SHUSHAN, E., THOMPSON, J.R., GUDAS, L.J. and BERGMAN, Y. (1998) Rex-1, a gene encoding a transcription factor expressed in the early embryo, is regulated via oct- $3 / 4$ and oct- 6 binding to an octamer site and a novel protein, rox-1, binding to an adjacent site. $\mathrm{Mo} / \mathrm{Ce} / / \mathrm{BiO} / 18$ : 1866-78.

BROCCOLI, D., SMOGORZEWSKA, A., CHONG, L. and DE LANGE, T. (1997). Human telomeres contain two distinct myb-related proteins, trf1 and trf2. Nat Genet 17: 231-5.

CHAMBERS, I., COLBY, D., ROBERTSON, M., NICHOLS, J., LEE, S., TWEEDIE, S. and SMITH, A. (2003). Functional expression cloning of nanog, a pluripotency sustaining factor in embryonic stem cells. Cel/113: 643-55.

DRUKKER, M., KATZ, G., URBACH, A., SCHULDINER, M., MARKEL, G., ITSKOVITZ-ELDOR, J., REUBINOFF, B., MANDELBOIM, O. and BENVENISTY, N. (2002). Characterization of the expression of mhc proteins in human embryonic stem cells. Proc Natl Acad Sci USA 99: 9864-9.

DYCE, P.W., WEN, L. and LI, J. (2006). In vitro germline potential of stem cells derived from fetal porcine skin. Nat Cell Bio/8: 384-90.

FERNANDEZ-GONZALEZ, R., MOREIRA, P., BILBAO, A., JIMENEZ, A., PEREZCRESPO, M., RAMIREZ, M.A., RODRIGUEZ DE FONSECA, F., PINTADO, B. and GUTIERREZ-ADAN, A. (2004). Long-term effect of in vitroculture of mouse embryos with serum on mrna expression of imprinting genes, development and behavior. Proc Natl Acad Sci USA 101: 5880-5.

GIDEKEL, S., PIZOV, G., BERGMAN, Y. and PIKARSKY, E. (2003). Oct-3/4 is a dose-dependent oncogenic fate determinant. Cancer Cel/4: 361-70.

GINIS, I., LUO, Y., MIURA, T., THIES, S., BRANDENBERGER, R., GERECHT-
NIR, S., AMIT, M., HOKE, A., CARPENTER, M.K., ITSKOVITZ-ELDOR, J. et al. (2004). Differences between human and mouse embryonic stem cells. Dev Biol 269: 360-80.

GUTIERREZ-ADAN, A. and PINTADO, B. (2000). Effect of flanking matrix attachment regions on the expression of microinjected transgenes during preimplantation development of mouse embryos. Transgenic Res 9: 81-9.

HATTORI, N., NISHINO, K., KO, Y.G., HATTORI, N., OHGANE, J., TANAKA, S and SHIOTA, K. (2004). Epigenetic control of mouse oct-4 gene expression in embryonic stem cells and trophoblast stem cells. J Biol Chem 279: 17063-9.

HILARIO, E., ALVAREZ, A., SIMON, J., GARCIA-SANZ, M., LACALLE, J. and ARECHAGA, J. (2001). Presence of four stem cell populations in monolayer cultures derived from teratocarcinoma embryoid bodies. In Vivo 15: 217-26.

HUMPHERYS, D., EGGAN, K., AKUTSU, H., HOCHEDLINGER, K., RIDEOUT, W.M., 3RD, BINISZKIEWICZ, D., YANAGIMACHI, R. and JAENISCH, R. (2001). Epigenetic instability in es cells and cloned mice. Science 293: 95-7.

JIMENEZ, A., FERNANDEZ, R., MADRID-BURY, N., MOREIRA, P.N., BORQUE, C., PINTADO, B. and GUTIERREZ-ADAN, A. (2003). Experimental demonstration that pre- and post-conceptional mechanisms influence sex ratio in mouse embryos. Mol Reprod Dev66: 162-5.

KUES, W.A., PETERSEN, B., MYSEGADES, W., CARNWATH, J.W. and NIEMANN, $H$. (2005). Isolation of murine and porcine fetal stem cells from somatic tissue. Biol Reprod 72: 1020-8.

LANE, N., DEAN, W., ERHARDT, S., HAJKOVA, P., SURANI, A., WALTER, J. and $R E I K, W$. (2003). Resistance of iaps to methylation reprogramming may provide a mechanism for epigenetic inheritance in the mouse. Genesis 35: 88-93.

LEAHY, A., XIONG, J.W., KUHNERT, F. and STUHLMANN, H. (1999). Use of developmental marker genes to define temporal and spatial patterns of differentiation during embryoid body formation. J Exp Zoo/284: 67-81.

LEE, M.K., HANDE, M.P. and SABAPATHY, K. (2005). Ectopic mtert expression in mouse embryonic stem cells does not affect differentiation but confers resistance to differentiation- and stress-induced p53-dependent apoptosis. J Cel/ Sci 118: 819-29.

LONERGAN, P., RIZOS, D., GUTIERREZ-ADAN, A., MOREIRA, P.M., PINTADO, B., DE LA FUENTE, J. and BOLAND, M.P. (2003). Temporal divergence in the pattern of messenger rna expression in bovine embryos cultured from the zygote to blastocyst stage in vitro or in vivo. Biol Reprod 69: 1424-31.

LU, S.J., QUAN, C., LI, F., VIDA, L. and HONIG, G.R. (2002). Hematopoietic progenitor cells derived from embryonic stem cells: Analysis of gene expression. Stem Cells 20: 428-37.

MCDONALD, F.J. and HEATH, J.K. (1994). Developmentally regulated expression of fibroblast growth factor receptor genes and splice variants by murine embryonic stem and embryonal carcinoma cells. Dev Genet 15: 148-54.

MITSUI, K., TOKUZAWA, Y., ITOH, H., SEGAWA, K., MURAKAMI, M., TAKAHASHI, K., MARUYAMA, M., MAEDA, M. and YAMANAKA, S. (2003). The homeoprotein nanog is required for maintenance of pluripotency in mouse epiblast and es cells. Cel/113: 631-42.

MORITA, Y., TSUTSUMI, O., OKA, Y. and TAKETANI, Y. (1994). Glucose transporter glut1 mrna expression in the ontogeny of glucose incorporation in mouse preimplantation embryos. Biochem Biophys Res Commun 199: 1525-31.

O'SHEA, K.S. (2004). Self-renewal vs. Differentiation of mouse embryonic stem cells. Biol Reprod 71: 1755-65.

OKAMOTO, K., OKAZAWA, H., OKUDA, A., SAKAI, M., MURAMATSU, M. and HAMADA, H. (1990). A novel octamer binding transcription factor is differentially expressed in mouse embryonic cells. Cel/60: 461-72.

PAN, G., LI, J., ZHOU, Y., ZHENG, H. and PEI, D. (2006). A negative feedback loop of transcription factors that controls stem cell pluripotency and self-renewal. FASEB J. 20: 1730-2

PEASTON, A.E., EVSIKOV, A.V., GRABER, J.H., DE VRIES, W.N., HOLBROOK, A.E., SOLTER, D. and KNOWLES, B.B. (2004). Retrotransposons regulate host genes in mouse oocytes and preimplantation embryos. Dev Cel/7: 597606.

PERICUESTA, E., RAMIREZ, M.A., VILLA-DIAZ, A., RELANO-GINES, A., TORRES, J.M., NIETO, M., PINTADO, B. and GUTIERREZ-ADAN, A. (2006). The proximal promoter region of mtert is sufficient to regulate telomerase activity in es cells and transgenic animals. Reprod Biol Endocrino/4: 5.

RAMIREZ, M.A., PERICUESTA, E., FERNANDEZ-GONZALEZ, R., MOREIRA, P., 
PINTADO, B. and GUTIERREZ-ADAN, A. (2006). Transcriptional and posttranscriptional regulation of retrotransposons iap and muerv-l affect pluripotency of mice es cells. Reprod Biol Endocrino/4: 55.

RIZOS, D., LONERGAN, P., BOLAND, M.P., ARROYO-GARCIA, R., PINTADO, B., DE LA FUENTE, J. and GUTIERREZ-ADAN, A. (2002). Analysis of differential messenger rna expression between bovine blastocysts produced in different culture systems: Implications for blastocyst quality. Biol Reprod 66: 589-95.

ROY, N.S., CLEREN, C., SINGH, S.K., YANG, L., BEAL, M.F. and GOLDMAN, S.A. (2006). Functional engraftment of human es cell-derived dopaminergic neurons enriched by coculture with telomerase-immortalized midbrain astrocytes. Nat Med. 12: 1295-68.

SLOTKIN, R.K. and MARTIENSSEN, R. (2007). Transposable elements and the epigenetic regulation of the genome. Nat Rev Genet 8: 272-85.

SUTTON, J., COSTA, R., KLUG, M., FIELD, L., XU, D., LARGAESPADA, D.A., FLETCHER, C.F., JENKINS, N.A., COPELAND, N.G., KLEMSZ, M. et al. (1996). Genesis, a winged helix transcriptional repressor with expression restricted to embryonic stem cells. J Biol Chem 271: 23126-33.

TAUPIN, P. (2006). Derivation of embryonic stem cells for cellular therapy: Challenges and new strategies. Med Sci Monit 12: RA75-8.

THOMSON, J.A., ITSKOVITZ-ELDOR, J., SHAPIRO, S.S., WAKNITZ, M.A., SWIERGIEL, J.J., MARSHALL, V.S. and JONES, J.M. (1998). Embryonic stem cell lines derived from human blastocysts. Science 282: 1145-7.

WARD, C.M., BARROW, K.M. and STERN, P.L. (2004). Significant variations in differentiation properties between independent mouse es cell lines cultured under defined conditions. Exp Cell Res 293: 229-38.

Received: 5 th December 2006 Reviewed by Referees: 26th January 2007 Modified by Authors and Accepted for Publication: 17th April 2007 Published Online: 25 June 2007

\section{Related, previously published Int. J. Dev. Biol. articles}

See our Special Issue on Mammalian Reproduction and Development edited by Brigid Hogan and in honor of Anne Mc. Laren at: http://www.ijdb.ehu.es/web/contents.php?vol=45\&issue=3

Selection of reference genes in mouse embryos and in differentiating human and mouse ES cells Erik Willems, lleana Mateizel, Caroline Kemp, Greet Cauffman, Karen Sermon and Luc Leyns Int. J. Dev. Biol. (2006) 50: 627-635

Morphogenesis, plasticity and irreversibility Chikara Furusawa and Kunihiko Kaneko Int. J. Dev. Biol. (2006) 50: 223-232

APC dosage effects in tumorigenesis and stem cell differentiation Claudia Gaspar and Riccardo Fodde Int. J. Dev. Biol. (2004) 48: 377-386

A P19Cl6 GFP reporter line to quantify cardiomyocyte differentiation of stem cells. Jennifer C Moore, Rene Spijker, Anton C Martens, Teun de Boer, Martin B Rook, Marcel A G van der Heyden, Leon G Tertoolen and Christine L Mummery Int. J. Dev. Biol. (2004) 48: 47-55

Mechanics in embryogenesis and embryonics: prime mover or epiphenomenon? Richard Gordon

Int. J. Dev. Biol. (2006) 50: 245-253

Differentiation of human embryonic stem cells into hepatocytes in 2D and 3D culture systems in vitro Hossein Baharvand, Seyed M. Hashemi, Saeid Kazemi Ashtiani and Ali Farrokhi Int. J. Dev. Biol. (2006) 50: 645-652

Expression of regulatory genes for pancreas development during murine embryonic stem cell differentiation Josué K. Mfopou, Erik Willems, Luc Leyns and Luc Bouwens Int. J. Dev. Biol. (2005) 49: 915-922

The instability of the neural crest phenotypes: Schwann cells can differentiate into myofibroblasts Carla Real, Corinne Glavieux-Pardanaud, Pierre Vaigot, Nicole Le Douarin and Elisabeth Dupin Int. J. Dev. Biol. (2005) 49: 151-159

Derivation of keratinocyte progenitor cells and skin formation from embryonic stem cells. Daniel Aberdam Int. J. Dev. Biol. (2004) 48: 203-206

Targeted disruption of fibroblast growth factor receptor-1 blocks maturation of visceral endoderm and cavitation in mouse embryoid bodies.

Milan Esner, Jiri Pachernik, Ales Hampl and Petr Dvorak

Int. J. Dev. Biol. (2002) 46: 817-825 


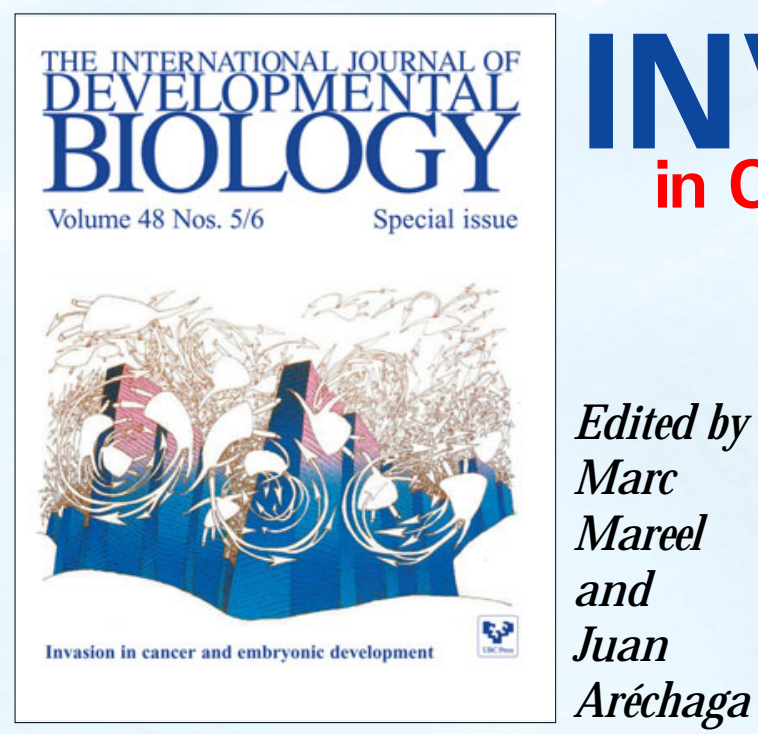

Vol. 48, Nos. 5/ 6

"I do not understand my images and anyone is free to understand them as he wishes. I have only tried to depict my own dreams..." J.M. Folon. This neo-surrealist painting entitled "Invasion" by Jean-Michel Folon (1934, Brussels, Belgium), with its swirling components against a stable background can be considered as a representation of avid cells breaking through the basement membrane to invade the adjacent stroma. With kind permission from J.-M. Folon (2004)

\section{Preface}

by $M$ arc $M$ areel and Juan A réchaga

\section{ONCOGENES, TUMOR SUPPRESSOR GENES \\ \& GENETIC REGULATION}

Molecular cell biology and cancer metastasis.

An interview with $\mathrm{G}$ arth Nicolson

by $\mathrm{M}$ arc $\mathrm{M}$ aree

Transcriptional regulation of cadherins

during development and carcinogenesis

by $\mathrm{H}$ éctor Peinado, Francisco Portillo and Amparo Cano

APC dosage effects in tumorigenesis and stem cell differentiation

by Claudia Gaspar and Riccardo Fodde

\section{ACTIVITIES OF INVASIVE CELLS}

Discovery and characterization of the cadherin family of cell adhesion molecules. An interview with Masatoshi Takeichi

by Douglas Sipp

Cadherin-mediated cell-cell adhesion and tissue

segregation in relation to malignancy

by Ramsey A. Foty and M alcolm S. Steinberg

Matrix metalloproteinases in cancer: from new functions to improved inhibition strategies

by Alicia R. Folgueras, Alberto M. Pendás, L uis M. Sánchez

and Carlos López-0 tín

Cytoskeletal mechanisms responsible for invasive migration of neoplastic cells

by Jury M. Vasiliev

Collective cell migration in morphogenesis and cancer

by Peter Friedl, Yael H egerfeldt and M iriam T usch
Invasive growth: a genetic program

by Alessandra Gentileand Paolo M. Comoglio

\section{INVASION SIGNALING PATHWAYS}

From here to there; a life based on migration.

An interview with Isaiah J. Fidler

by lan R. H art

$\mathbf{N}$-cadherin in the spotlight of cell-cell adhesion, differentiation, embryogenesis, invasion and signalling

by L ara D.M. Derycke and M arc E. Bracke

The Wnt connection to tumorigenesis

by Jürgen Behrens and Barbara L ustig

The chemokine network in cancer - much more than directing cell movement

by $\mathrm{H}$ agen Kulbe, $\mathrm{N}$ eil R. Levinson, Fran Balkwill and Julia L. Wilson

\section{PARTICIPATION OF THE HOST}

Brain tumour development and invasion.

An interview with O le Didrik Laerum

by Dieter $\mathrm{F}$. $\mathrm{H}$ ülser

The stroma reaction myofibroblast:

a key player in the control of tumor cell behavior

by A lexis Desmoulière, Christelle Guyot and Giulio Gabbiani

The countercurrent principle in invasion and metastasis of cancer cells. Recent insights on the roles of chemokines

by Ghislain Opdenakker and Jo Van Damme

\section{NORMAL EMBRYONIC INVADERS}

\& THEIR MALIGNANT COUNTERPARTS

The migration and differentiation of a chemist entangled in developmental and cancer biology. An interview with Jean-Paul Thiery

by Fred T. Bosman

Primordial germ cell migration

by Kathleen M olyneaux and Christopher Wylie

Germinal tumor invasion and the role of the testicular stroma

by Alejandro Díez-T orre, Unai Silván, Olivier DeWever,

Erik Bruyned, M arc M ared and Juan Aréchaga

\section{METHODOLOGY}

Tumor invasion and metastasis: getting more basic to come closer to the patient. An interview with Lance A. Liotta

by Vincent Castronovo

The "chemoinvasion assay" : a tool to study tumor and endothelial cell invasion of basement membranes

by Adriana Albini, Roberto Benelli, Douglas M. N oonan and Claudio Brigati

Novel technologies and recent advances in metastasis research

by Ivana Crnic and Gerhard Christofori

\section{THERAPEUTIC ASPECTS}

Parallels in invasion and angiogenesis provide pivotal points for therapeutic intervention by Suzanne A. Eccles

Pain control by ionizing radiation of bone metastasis

by LuCA.M .-L. Vakaet and T om B oterberg

\section{ORDER FORM}

I would like to order cop(y/ies) of the Int. J. Dev. Biol. Special Issue “Invasion in Cancer \& Embryonic Development” (Vol. 48, Nos. 5/6) at US\$ 90 or Euro $€ 70$ per copy (including post and packaging). Total to be charged: US\$ / Euro $€$ (please specify currency)

\section{ORDER BY}

$\checkmark$ Web: http://www.intjdevbiol.com

$\checkmark$ E-mail: ijdb@ehu.es (include the information indicated above)

$\checkmark$ FAX: +34-94-601-3266

$\checkmark$ POST: to the address shown to the right
The International Journal of Developmental Biology

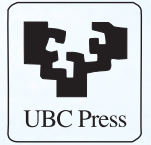

Editorial Office, Uni. of the Basque Country

Dept. Cell Biology and Histology

Faculty of Medicine, E-48940 Leioa

Vizcaya, SPAIN 